\title{
In Vivo Hepato-Nephroprotective Role of Nigella sativa Seed Extract Against Lead Nitrate $\left[\mathrm{Pb}\left(\mathrm{NO}_{3}\right)_{2}\right]$ Induced Toxicity in Albino Mice
}

\author{
Kürşad YAPAR ${ }^{1} \quad$ Kültiğin ÇAVUŞOĞLU ${ }^{2} \quad$ Emine YALÇIN $^{2 *} \quad$ Ali ACAR $^{3} \quad$ Baran SEVEN ${ }^{4}$
}

\begin{abstract}
In this study, toxic effects of lead nitrate $\left[\mathrm{Pb}\left(\mathrm{NO}_{3}\right)_{2}\right]$ and the hepato-nephroprotective role of Nigella sativa seed extract (NSSE) against toxicity were studied in albino mice. For this aim, mice were randomly divided into six groups as: Group I treated with tap water, Group II: $300 \mathrm{mg} \mathrm{kg-}$ bw NSSE, Group III: $600 \mathrm{mg} \mathrm{kg}^{-1}$ bw NSSE, Group IV: $500 \mathrm{mg} \mathrm{kg}^{-1}$ bw Pb(NO$)_{2}$, Group V: $300 \mathrm{mg}$ $\mathrm{kg}^{-1}$ bw NSSE+500 mg kg-1 bw Pb(NO $)_{2}$, Group VI: $600 \mathrm{mg} \mathrm{kg}^{-1}$ bw NSSE+500 mg kg bw $\mathrm{Pb}\left(\mathrm{NO}_{3}\right)_{2}$. After experimental procedure the changes in blood urea nitrogen (BUN), creatinine, alanine transaminase (ALT), aspartate transaminase (AST) levels of blood serum, glutathione (GSH) and malondialdehyde (MDA) levels of liver and kidney tissues were investigated. And also histopathological examinations of liver and kidney tissues were studied. At result, significant increases were observed in BUN, creatinine, ALT, AST levels of mice treated with $\mathrm{Pb}\left(\mathrm{NO}_{3}\right)_{2}$. GSH levels were decreased, MDA levels were increased in kidney and liver tissues after $\mathrm{Pb}\left(\mathrm{NO}_{3}\right)_{2}$ treatment. In histopathological examinations binucleated cell, karyomegaly, stellate cell and bilirubin pigment deposit were observed in liver tissue while hyaline cast, thickening of the basement membrane, albumonid content and inflammatory leukocytes were observed in kidney tissue in Group IV. NSSE treatment in Group V and VI was ameliorated the toxic changes in level of serum parameters, GSH and MDA levels and histopathological damages of tested tissues. As a result, it was determined that NSSE decreases hepato-nephrotoxicity with a dose dependent manner induced by $\mathrm{Pb}\left(\mathrm{NO}_{3}\right)_{2}$ and leads to an improvement associated with its components.
\end{abstract}

Keywords: Biochemical parameters, glutathione, lead nitrate, malondialdehyde, Nigella sativa seed extract

\footnotetext{
Kürşad YAPAR (Orcid ID: 0000-0003-0287-4521), Giresun University, Department of Pharmacology, Faculty of Medicine, Giresun, Turkey.

2 Kültiğin ÇAVUŞOĞLU (Orcid ID: 0000-0002-4767-9132), Emine YALÇIN (Orcid ID: 0000-0002-5280-5375), Giresun University, Department of Biology, Faculty of Science and Art, Giresun, Turkey.

${ }^{3}$ Ali ACAR (Orcid ID: 0000-0001-8617-2206), Giresun University, Vocational School of Health Services, Department of Medical Services and Techniques, Giresun, Turkey.

${ }^{4}$ Baran SEVEN (Orcid ID: 0000-0002-8640-5935), Giresun University, Institute of Science and Technology, Department of Biology, Giresun, Turkey.

* Sorumlu Yazar/Corresponding Author: Emine YALÇIN, e-mail: emine.yalcin@giresun.edu.tr The article was presented as a poster at the Ecology Congress held in Kayseri on May 11-13, 2017.

ETIKK KURUL ONAYI / ETHICS COMMITTEE APPROVAL: Bu makale yer alan hayvan deneyi için "Giresun Üniversitesi Hayvan Deneyleri Yerel Etik Komisyonu”nun Karar Tarih: 27.04.2016 ve Karar No:2016/01 sayıl1 kararı ile Etik Kurul Onayı almıştır.
} 


\section{INTRODUCTION}

The rapid increase in the world's population and the industrialization has brought along many problems. Environmental pollution and the negative impacts of pollution on living organisms are the most important problems. Nowadays, various chemical substances are used in many sectors in industrial sectors. Heavy metals are chemicals frequently used in industrial areas which cause environmental pollution and have serious toxic effects on living organisms. Heavy metals are elements with a specific gravity greater than $5 \mathrm{~g} \mathrm{~cm}^{-3}$ and an atomic number greater than 20 (Kafadar and Saygideger, 2010). Heavy metals contaminate the environment by natural ways or by various industrial activities. Natural contamination is caused by soil erosion, volcanic activity and atmospheric particles, while industrial contamination occurs as a result of metal processing, textile and nuclear sectors (Gur et al., 2004). Lead ( $\mathrm{Pb})$ is one of the most toxic elements naturally occurring on Earth and is one of the most utilized metals in the world. $\mathrm{Pb}$ contaminates the environment, especially the atmosphere as a metal or compound and has high toxicity due to its accumulation properties. $\mathrm{Pb}$ is used in the production of petrol additives, automobile parts, pesticides and batteries. Moreover, urban wastes, exhaust fumes of vehicles, mineral and volcanic activities, fertilizers and drugs used in agriculture are the main causes of $\mathrm{Pb}$ contamination (Kennedy and Gonsalves, 1987; Abdullahi, 2013). No matter which exposure occurs $\mathrm{Pb}$ exposure causes serious toxic effects on organisms. Kidneys and liver are severely affected by $\mathrm{Pb}$ toxicity and high $\mathrm{Pb}$ concentrations can cause brain damage, seizures, coma and death. In many studies, $\mathrm{Pb}$ exposure was reported to cause fatigue, nervousness, decreased sensory and motor reaction times, cardiovascular system disorders and myocardial infarction (Abdullahi, 2013).
The usage of natural supplements without side effects against the toxic effects of chemicals is quite popular recently. Nigella sativa seed is a natural nutrient that has a long established historical basis for health problems which is belongs to the Ranunculaceae family (Ahmad et al., 2014). NSS contains different constituents such as carbohydrates, fats, essential amino acids, vitamins and is a strong source of potassium, calcium and iron. Studies in the literature have shown that Nigella sativa seed extract (NSSE) has antimicrobial, antiinflammatory, antihypertensive, analgesic, anticarcinogenic, hypoglycemic, hepatoprotective and antioxidant effects (Shrivastava et al., 2011; Norsharina et al., 2011). The activity of NSSE is mostly due to oil and quinone components, and in particular, 30$48 \%$ of the total compounds constitute timocinone, which is an important bioactive component. Other functional components of the NSSE include p-cymene, carvacrol, thymohydroquinone, dihydrothymoquinone, $\alpha$ thujene, thymol, t-anethole, p-pinene, a-pinene and p-terpinen (Norsharina et al., 2011).

In this study, toxic effects of $\mathrm{Pb}\left(\mathrm{NO}_{3}\right)_{2}$ were investigated by terms of biochemical aspects in albino mice and protective role of NSSE against the toxic effects was investigated. ALT and AST were investigated as liver damage markers and also BUN and creatinine were as renal failure indicator. In order to evaluate the antioxidant balance in kidney and liver tissues, GSH and MDA levels were also investigated. The histopathological preparations of both tissues were examined and the damages were revealed in detail.

\section{MATERIAL AND METHODS}

\section{Animals and Chemical}

$\mathrm{Pb}\left(\mathrm{NO}_{3}\right)_{2}$ and other chemicals were obtained from Sigma-Aldrich Inc. NSSEE (grounded black seed powder) was obtained from 1001Natural. In this study, 36 adult Mus 
musculus var. albinos mice with 25-30 g weight maintained in Giresun University Experimental Animals Research Laboratory were used.

\section{Experimental Protocol}

The experiments were carried out with 36 male Mus musculus var. albino mice (12-14 weeks old, body weight of 25-30 g). The mice were housed in stainless steel cages and kept under controlled conditions at $22 \pm 3^{\circ} \mathrm{C}, 55 \pm 5 \%$ relative humidity and a 12 -hour light/dark cycle throughout the experiment. In this study, the methods and techniques applied to mice were carried out according to the guidelines set by the World Health Organization (Geneva, Switzerland) and the ethical standards of the local ethical committee for animal experiments at Giresun University (Protocol date: 27.04.2016, Decision number: 2016/01).

Animals were assigned to 6 groups, 1 as control and 5 as treatment groups and each group contained 6 animals. During the 10 weeks application period, mice in the control group were fed orally with tap water and mice in the Group II and Group III were respectively fed orally with $300 \mathrm{mg} \mathrm{kg}^{-1}$ bw and $600 \mathrm{mg} \mathrm{kg}^{-1}$ bw doses of NSSE. Mice in Group IV were fed orally with $500 \mathrm{mg} \mathrm{kg}^{-1}$ bw $\mathrm{Pb}$, mice in Group V were fed orally with $500 \mathrm{mg} \mathrm{kg}^{-1}$ bw $\mathrm{Pb}+300 \mathrm{mg}$ $\mathrm{kg}^{-1}$ bw NSSE seeds and mice in Group VI were fed orally with $500 \mathrm{mg} \mathrm{kg}^{-1}$ bw $\mathrm{Pb}+600 \mathrm{mg} \mathrm{kg}^{-1}$ bw NSSE.

\section{Serum Analysis}

For serum isolation, whole blood samples were collected by cardiac puncture under mild ether anesthesia. Blood samples were transferred directly into plain vacutainer tubes, centrifuged at $1200 \mathrm{~g}$ for $10 \mathrm{~min}$ at $4{ }^{\circ} \mathrm{C}$ and stored at $-20{ }^{\circ} \mathrm{C}$ until analysis. Blood BUN (Teco Diagnostics, CAT. NO: B549-150, USA), creatinine (Teco Diagnostics, CAT. NO: C513-480, USA), AST (Teco Diagnostics, AST/GOT Liquid Reagent, CAT.NO: A559-150, U.S.A) and ALT (Teco Diagnostics, ALT/GPT Liquid Reagent, CAT.
NO: A524-150, U.S.A) levels were measured by using commercially available test kits with a Medispec 99 M Chemistry autoanalyzer.

\section{GSH and MDA Analysis}

At the end of the treatment period, animals were sacrificed after an overnight fasting, by exsanguinations under ether anesthesia. The liver and kidney tissues of each animal were removed, cleaned, dried and processed for biochemical measurements. The tissues were homogenized in cold $0.15 \mathrm{M} \mathrm{KCI}$ by a homogenizer (Ultraturrax Type T25-B, IKA Labartechnie) at $16000 \mathrm{rpm}$ for $3 \mathrm{~min}$. The homogenates were centrifuged at $5000 \mathrm{~g}$ at $4^{\circ} \mathrm{C}$ for $1 \mathrm{~h}$. The supernatants were stored at $-40^{\circ} \mathrm{C}$ until they were analyzed. Tissue GSH and MDA contents were measured colorimetrically as described by Beutler et al., (1963) and Yoshoiko et al., (1979), respectively.

\section{Histopathological Examination}

For histopathological examination, fresh tissue samples of liver and kidney were fixed in $10 \%$ neutral buffered formalin solution for routine processing and embedded in paraffin wax sectioned at 5 micron then stained with Hematoxylin and Eosin (H-E). Histopathological changes were semiquantitatively assessed under a light microscope with an ocular with grids and $4 x$, 10x, 40x objective, respectively.

\section{Statistical Analysis}

The statistical analyses were carried out with SPSS for Windows v22.0 (IBM Corp.). Results were analyzed using one-way ANOVA and Duncan's test. Data for MDA and GSH were given as mean \pm standard error (SE), while the mean \pm standard deviation (SD) was shown for AST, ALT, BUN and creatinine, and values of $\mathrm{p}<0.05$ are considered statistically significant. 


\section{RESULTS AND DISCUSSION}

\section{Biochemical Changes}

The effects of $\mathrm{Pb}\left(\mathrm{NO}_{3}\right)_{2}$ and NSSE treatment on some biochemical parameters of mice were shown in Table 1. Both dose of NSSE administration in Group II and III did not alter the level of serum parameters when compared to the control values. The levels of selected parameters showed similar levels in Group I, II and III. These results indicate that both doses of NSSE treatment-alone do not cause any changes in AST, ALT, BUN and creatinine levels. However, significant changes were observed in $\mathrm{Pb}\left(\mathrm{NO}_{3}\right)_{2}$ treated group $(\mathrm{p}<0.05)$. AST, ALT, BUN and creatinine levels were 1.75, 1.59, 1.66,
2.82 times higher in Group IV compared to control group. This result showed that creatinine level was more sensitive to $\mathrm{Pb}\left(\mathrm{NO}_{3}\right)_{2}$ toxicity compared to other parameters. In Group V and VI, NSSE administration with $\mathrm{Pb}\left(\mathrm{NO}_{3}\right)_{2}$ treatment significantly reverted the increase of AST, ALT, BUN and creatinine levels. For confirm this hypothesis, it can be said that creatinine level was found as 2.82 times and 1.77 times higher than control level in Group IV and Group VI, respectively. This result concluded that NSSE treatment decreased the $\mathrm{Pb}\left(\mathrm{NO}_{3}\right)_{2}$ induced toxicity and showed a protective effect in a rate of $63 \%$. These results can be explained by protective role of NSSE.

Table 1. The effects of $\mathrm{Pb}\left(\mathrm{NO}_{3}\right)_{2}$ and NSSE treatment on some biochemical parameters

\begin{tabular}{lcccc}
\hline & $\begin{array}{c}\text { AST } \\
\left(\mathrm{U} \mathrm{L}^{-1}\right)\end{array}$ & $\begin{array}{c}\text { ALT } \\
\left(\mathrm{U} \mathrm{L}^{-1}\right)\end{array}$ & $\begin{array}{c}\text { BUN } \\
\left(\mathrm{mg} \mathrm{L}^{-1}\right)\end{array}$ & $\begin{array}{c}\text { Creatinine } \\
\left(\mathrm{mg} \mathrm{L}^{-1}\right)\end{array}$ \\
\hline Group I & $35.54 \pm 3.72^{\mathrm{d}}$ & $44.15 \pm 2.69^{\mathrm{d}}$ & $19.33 \pm 2.10^{\mathrm{d}}$ & $2.14 \pm 0.53^{\mathrm{c}}$ \\
Group II & $35.24 \pm 4.13^{\mathrm{d}}$ & $43.51 \pm 2.53^{\mathrm{d}}$ & $19.37 \pm 2.03^{\mathrm{d}}$ & $2.10 \pm 0.53^{\mathrm{c}}$ \\
Group III & $34.88 \pm 3.26^{\mathrm{d}}$ & $44.09 \pm 1.88^{\mathrm{d}}$ & $19.49 \pm 2.02^{\mathrm{d}}$ & $2.16 \pm 0.35^{\mathrm{c}}$ \\
Group IV & $62.05 \pm 2.68^{\mathrm{a}}$ & $70.26 \pm 3.07^{\mathrm{a}}$ & $32.12 \pm 2.77^{\mathrm{a}}$ & $6.03 \pm 0.91^{\mathrm{a}}$ \\
Group V & $51.52 \pm 2.69^{\mathrm{b}}$ & $58.53 \pm 4.46^{\mathrm{b}}$ & $27.74 \pm 2.64^{\mathrm{b}}$ & $4.50 \pm 0.71^{\mathrm{b}}$ \\
Group VI & $40.53 \pm 2.72^{\mathrm{c}}$ & $50.20 \pm 3.41^{\mathrm{c}}$ & $22.54 \pm 2.14^{\mathrm{c}}$ & $3.79 \pm 0.81^{\mathrm{b}}$ \\
\hline
\end{tabular}

*Means with the different letters in the same column are statistically significant $(\mathrm{p}<0.05)$

\section{Oxidative Stress and Lipid Peroxidation}

The effects of $\mathrm{Pb}\left(\mathrm{NO}_{3}\right)_{2}$ and NSSE treatment on MDA and GSH levels of liver and kidney tissues was shown in Figure 1 and Figure 2. The levels of MDA and GSH levels in related tissues showed similar rates in Group I, II and III. However, MDA and GSH level of liver and kidney tissues showed significant changes after $\mathrm{Pb}\left(\mathrm{NO}_{3}\right)_{2}$ treatment. Namely, $\mathrm{Pb}\left(\mathrm{NO}_{3}\right)_{2}$ treatment caused an increase in MDA levels of liver and kidney tissues but caused a decrease in GSH levels. After $\mathrm{Pb}\left(\mathrm{NO}_{3}\right)_{2}$ exposure, MDA levels of liver and kidney tissues were 2.16 and 1.99 times higher, GSH levels were 2.04 and 2.44 times lower compared to control, respectively. The administration of NSSE with $\mathrm{Pb}\left(\mathrm{NO}_{3}\right)_{2}$ treatment significantly ameliorated the changes in MDA and GSH levels, and these results can be explained by protective role of NSSE.

\section{Histopathological Changes}

Histopathology of liver and kidney tissues after $\mathrm{Pb}\left(\mathrm{NO}_{3}\right)_{2}$ treatment was also investigated. There were no change in the histological examinations of the kidney and liver tissues of Groups I, II and III. In histopathological examinations of $\mathrm{Pb}\left(\mathrm{NO}_{3}\right)_{2}$ treated kidney (Group IV) hyaline cast, thickening of the basement membrane, albumonid content and inflammatory leukocytes were observed (Figure $3 \mathrm{E}$ and $3 \mathrm{~F}$ ). Binucleated cell, karyomegaly, stellate cell and bilirubin pigment deposit were observed in $\mathrm{Pb}\left(\mathrm{NO}_{3}\right)_{2}$ treated liver tissue. Two different doses of NSSE treatment showed a partial improvement in the histopathological changes (Table 2). In Group V and VI, NSSE treatment significantly decreased the levels of histopathological findings compared to group IV. 


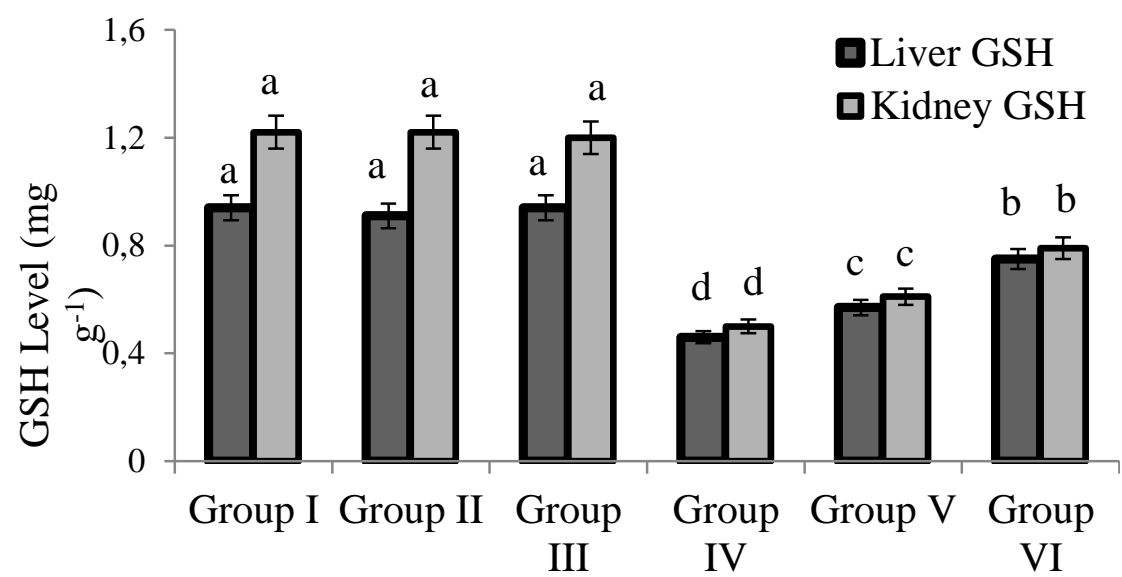

Figure 1. The effects of $\mathrm{Pb}\left(\mathrm{NO}_{3}\right)_{2}$ and NSSE treatment on GSH levels of liver and kidney. Each histogram is a decimal mean; the vertical lines above the bars indicate standard error. The averages indicated by different letters (a-d) were statistically significant $(\mathrm{p}<0.05)$.

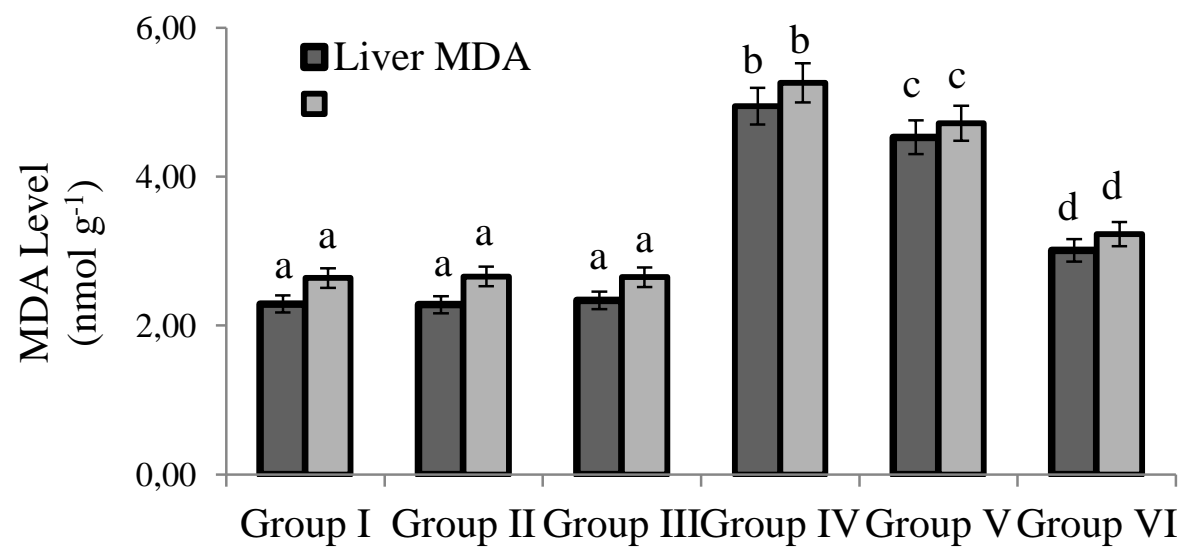

Figure 2. The effects of $\mathrm{Pb}\left(\mathrm{NO}_{3}\right)_{2}$ and NSSE treatment on MDA levels of liver and kidney tissues. Each histogram is a decimal mean; the vertical lines above the bars indicate standard error. The averages indicated by different letters (a-d) were statistically significant $(\mathrm{p}<0.05)$.

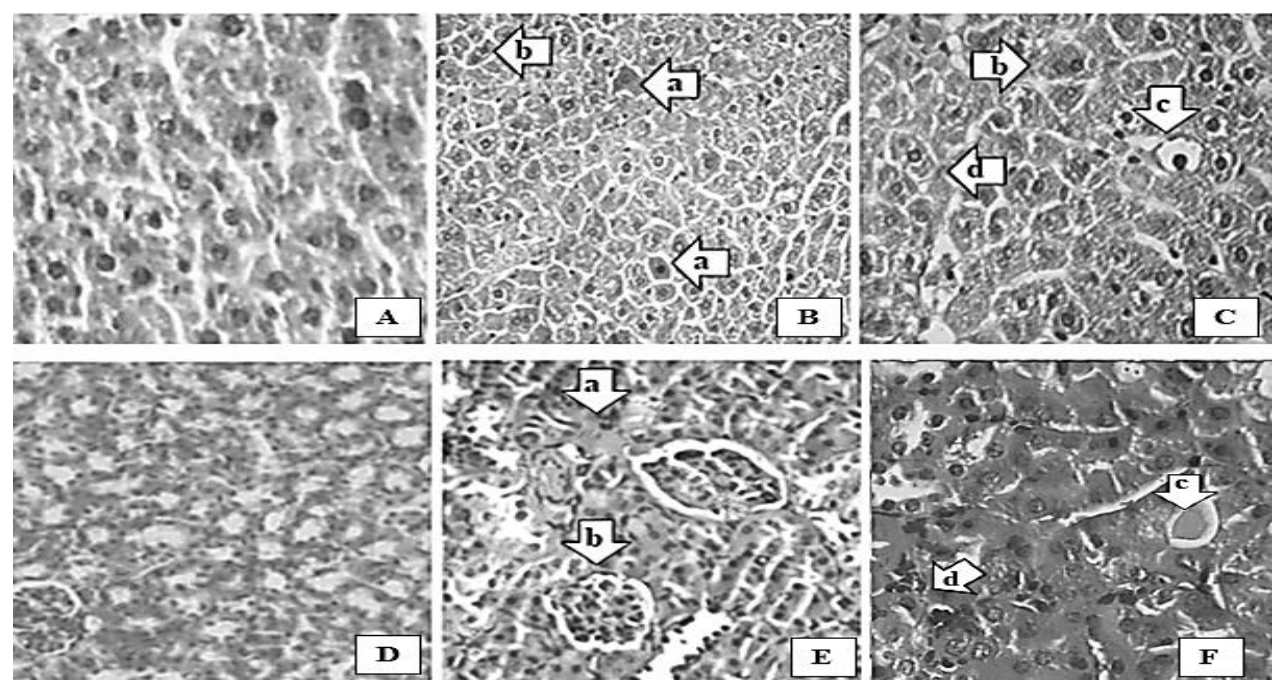

Figure 3. Histopathology of liver and kidney (A: control group of liver tissue, B: arrow a. karyomegaly, b. binucleated cell, $\mathrm{C}$ : arrow c. stellate cell, d. bilirubin pigment in $\mathrm{Pb}\left(\mathrm{NO}_{3}\right)_{2}$ treated liver, $\mathrm{D}$ : kidney tissue of the control group, E: arrow a. hyaline cast, b. thickening of the basement membrane, $\mathrm{C}$ : arrow c. albumonid content, d. inflammatory leukocytes in $\mathrm{Pb}\left(\mathrm{NO}_{3}\right)_{2}$ treated kidney) 
Table 2. Histopathological evaluation of tissues treated with $\mathrm{Pb}(\mathrm{NO} 3) 2$ and NSSE

\begin{tabular}{|c|c|c|c|c|c|c|}
\hline & Group I & Group II & Group III & Group IV & Group V & Group VI \\
\hline & \multicolumn{6}{|c|}{ Liver } \\
\hline Stellate cell & - & - & - & ++ & ++ & + \\
\hline Bilirubin pigment & - & - & - & + & + & - \\
\hline Karyomegaly & - & - & - & ++++ & +++ & ++ \\
\hline \multirow[t]{2}{*}{ Binucleated cell } & - & + & - & +++ & ++ & + \\
\hline & \multicolumn{6}{|c|}{ Kidney } \\
\hline Hyaline cast & - & - & - & +++ & ++ & + \\
\hline $\begin{array}{l}\text { Thickening of the } \\
\text { basement membrane }\end{array}$ & - & - & - & +++ & ++ & + \\
\hline Albumonid content & - & - & - & ++ & ++ & + \\
\hline Inflammatory leukocytes & - & - & - & ++++ & +++ & ++ \\
\hline
\end{tabular}

$*(-)$ : No change, $(+)$ : mild change, $(++)$ : moderate change, $(+++)$ : severe change, $(++++)$ : hard change

In this study, in vivo effects of $\mathrm{Pb}\left(\mathrm{NO}_{3}\right)_{2}$ in Swiss albino mice and the protective effects of NSSE against toxicity were investigated. According to histological and biochemical results, we confirmed that, $500 \mathrm{mg} \mathrm{kg}^{-1}$ $\mathrm{Pb}\left(\mathrm{NO}_{3}\right)_{2}$ exhibits toxic effects especially on liver and kidney tissues and NSSE show a protective effect against these toxic effects. After $\mathrm{Pb}\left(\mathrm{NO}_{3}\right)_{2}$ treatment, serum ALT and AST levels of albino mice showed a strong increase and elevated liver enzymes may indicate inflammation or degeneration of hepatic function and hepatic injury. These alterations observed in this study can be explained by the direct or indirect toxic effects of $\mathrm{Pb} . \mathrm{Pb}$ causes oxidative stress in cells and results in destruction of membrane lipids, proteins, cell membrane and consequently cell deformation (Kasperczyk et al. 2014). As a result of these toxic effects, normally the enzymes in the cytoplasm of hepatocytes pass into the bloodstream and the levels in the blood increase abnormally and this increase in serum AST and ALT levels indicates liver damage (Pari and Murugan, 2004; Stefano et al., 2006). Mazreku et al., (2017) observed significant increases in ALT and AST levels of albino mice treated with $90 \mathrm{mg} \mathrm{kg}^{-1} \mathrm{~Pb}$ (II) acetate and reported that the increase was more pronounced at AST level. In this study, serum BUN and creatinine levels showed a strong increase after $\mathrm{Pb}\left(\mathrm{NO}_{3}\right)_{2}$ treatment and this increase indicates renal damage. The nephrotic syndrome causes increases in blood levels of creatinine and BUN, which are two biochemical indicators of kidney damage (Ebert and Nagar, 2008). Similarly, Zhang et al., (2013) reported that serum BUN and creatinine levels were notably elevated in $40 \mathrm{mg} \mathrm{kg}^{-1}$ day $\mathrm{Pb}$ acetate treated mice.

In order to determine the effects of $\mathrm{Pb}\left(\mathrm{NO}_{3}\right)_{2}$ treatment on oxidative parameters MDA and GSH levels of liver and kidney of tissues were examined. As a result, a significant increase in MDA and a significant decrease in GSH levels of tissues exposed to $\mathrm{Pb}\left(\mathrm{NO}_{3}\right)_{2}$ were observed which is in agreement with the previous studies (Cavusoglu et al., 2011). Pb is reported to disrupt the antioxidant balance in the cell by causing oxidative damage (Kasperczyk et al. 2014). When the oxidant and antioxidant balance in the cell deteriorates, irreversible damage occurs in the cells. Therefore, changes in tissue GSH and MDA ratios are an important indicator of oxidative damage (Jones, 2002; Gilmore and Kirby, 2004). A decrease in GSH level and an increase in MDA level indicate oxidative damages in liver and kidney tissues induced by $\mathrm{Pb}\left(\mathrm{NO}_{3}\right)_{2}$. The increase in AST and ALT levels, and a change in liver MDA and GSH levels indicate significant liver damage. Similarly, an increase in BUN and creatinine levels, and a change in kidney MDA and GSH 
levels indicate kidney damage. Tissue histopathology was examined to confirm these results. In histopathological examinations hyaline cast, thickening of the basement membrane, albumonid content and inflammatory leukocytes were observed in $\mathrm{Pb}\left(\mathrm{NO}_{3}\right)_{2}$ treated kidney tissue. Binucleated cell, karyomegaly, stellate cell and bilirubin pigment deposit were observed in $\mathrm{Pb}\left(\mathrm{NO}_{3}\right)_{2}$ treated liver tissue. These findings are the evidence of pathological damages induced by $\mathrm{Pb}\left(\mathrm{NO}_{3}\right)_{2}$ in the liver and kidneys and support the changes in biochemical and oxidative parameters. Toxicity of $\mathrm{Pb}\left(\mathrm{NO}_{3}\right)_{2}$ observed in this study can be explained by $\mathrm{Pb}^{2+}$ toxicity which is ionized in water. $\mathrm{Pb}\left(\mathrm{NO}_{3}\right)_{2}$ readily dissolves in water to give $\mathrm{Pb}^{2+}$ and $\mathrm{NO}^{-3}$ ions. The ionic mechanism of $\mathrm{Pb}$ toxicity results from the ability to replace cations such as $\mathrm{Ca}$ and $\mathrm{Na}$. Such cations are very important for the survival and continuity of cells, and the replacement of these cations leads to inhibition of many metabolic pathways. Significant deterioration occurs in various biological processes such as cell adhesion, intracellular and intracellular signaling, protein folding, ionic transport, enzyme regulation (Flora et al., 2008). Deterioration of the cells affects the tissues and the damage to the tissues affects whole organism.

Also $300 \mathrm{mg} \mathrm{kg}^{-1}$ and $600 \mathrm{mg} \mathrm{kg}^{-1} \mathrm{NSSE}$ treatment in Group V and VI showed a partial improvement in biochemical parameters, GSH and MDA levels and exhibited a clear protective effect against pathological damages compared to Group IV. It was shown that NSSE treatment has a dose-dependent protective effect against $\mathrm{Pb}\left(\mathrm{NO}_{3}\right)_{2}$ toxicity. Many studies have demonstrated the analgesic, antilipemic, postcoital contraceptive, diuretic and antihypertensive, bronchodilator and calcium antagonist, histamine release inhibitor, hepatoprotective, anthelmintic, antifungal, antimicrobial, anticancer and anti-inflammatory activities of NSSE (Shrivastava et al., 2011; Ahmad et al., 2014). The majority of these activities are related to the phytochemical content of the seed. Phytochemical studies determined that more than 100 ingredients were found in NSSE. A combination of fatty acids, essential oils and trace elements is believed to contribute to the pharmacological activity. Several studies have demonstrated the antioxidant and protective activities of NSSE. The protective effect of NSSE observed in this study can be explained by the inhibiton of oxidative damage induced by $\mathrm{Pb}\left(\mathrm{NO}_{3}\right)_{2}$. Similar, Rastogi et al., (2010) have investigated the protective effects of $N$. sativa against radiationinduced oxidative damage and results indicated that $N$. sativa has a significant protection. Yesmin et al., (2013) examined the protective effects of $N$. sativa against liver damage associated with oxidative stress and reported that pretreatment with $N$. sativa decreased the serum ALT, hepatic MDA level and increased hepatic GSH in rats.

\section{CONCLUSION}

The $\mathrm{Pb}\left(\mathrm{NO}_{3}\right)_{2}$, which is frequently used in industrial areas and contaminated the environment, causes various toxic effects. In this study, the toxic effects of $\mathrm{Pb}\left(\mathrm{NO}_{3}\right)_{2}$ treatment in albino mice were evaluated by biochemical aspect and the protective effects of NSSE against these toxic effects were examined. As a result, it was observed that $\mathrm{Pb}\left(\mathrm{NO}_{3}\right)_{2}$ treatment causes abnormal changes in the biochemical parameters that indicate liver and kidney damage and cause serious pathological findings in these tissues. It has been found that NSSE decreases the toxicity in a dose dependent manner and leads to an improvement in all parameters. Therefore, it has been determined that NSSE can be used as a protective food against the toxic effects generated by chemicals, especially heavy metals. 


\section{ACKNOWLEDGEMENTS}

This study is financially supported by Giresun University Scientific Research Projects Department under SAĞ-BAP-A-140316-92 code project.

\section{REFERENCES}

Abdullahi MS, 2013. Toxic Effects of Lead in Humans: an Overview. Global Advanced Research Journal of Environmental Science and Toxicology, 2 (6): 157-162.

Ahmad I, Tripathi J, Sharma M, Karchulli MS, Umer L, 2014. Nigella sativa - a Medicinal Herb with Immense Therapeutic Potential (a Systematic Review). International Journal of Biological \& Pharmaceutical Research, 5: 755762.

Beutler E, Duron O, Kelly BM, 1963. Improved Method for the Determination of Blood Glutathione. Journal of Laboratory and Clinical Medicine, 61: 882-888.

Cavusoglu K, Yapar K, Oruc E, Yalcin E, 2011. The Protective Effect of Royal Jelly on chronic Lambda-Cyhalothrin Toxicity: Serum Biochemical Parameters, Lipid Peroxidation, and Genotoxic and Histopathological Alterations in Swiss Abino Mice. Journal of Medicinal Food, 14 (10): 1229-1237.

Ebert EC, Nagar M, 2008. Gastrointestinal Manifestations of Amyloidosis. American Journal of Gastroenterology, 103 (3): 776-787.

Flora SJS, Mittal M, Mehta A, 2008. Heavy Metal Induced Oxidative Stress \& Its Possible Reversal by Chelation Therapy. Indian Journal of Medical Research, 128: 501-523.

Gilmore WJ, Kirby GM, 2004. Endoplasmic Reticulum Stress Due to Altered Cellular Redox Status Positively Regulates Murine Hepatic CYP2A5 Expression. Journal of Pharmacology and Experimental Therapeutics, 308: 600-608.
Gur N, Topdemir A, Munzuroglu O, Cobanoglu D, 2004. Effects of Heavy Metals $\left(\mathrm{Cu}^{++}, \mathrm{Pb}^{++}\right.$, $\mathrm{Hg}^{++}, \mathrm{Cd}^{++}$) on Pollen Germination and Tube Growth of Clivia sp. Firat University Turkish Journal of Science \& Technology,16 (2): 177-182.

Jones DP, 2002. Redox Potential of GSH/GSSG Couple: Assay and Biological Significance. Methods in Enzymology, 348: 93-112.

Kafadar F, Saygideger S, 2010. Determ Ination of Lead $(\mathrm{Pb})$ Content in Some Agricultural Plants Irrigated with Industrial Waste Water Around Gaziantep Province. Ekoloji, 19 (75): 41-48.

Kasperczyk A, Slowinska-Lozynska L, Dobrakowski M, Zalejska-Fiolka J, Kasperczyk S, 2014. The Effect of Lead-Induced Oxidative Stress on Blood Viscosity and Rheological Properties of Erythrocytes in Lead Exposed Humans. Clinical Hemorheology and Microcirculation, 56 (3): 187-195.

Kennedy CD, Gonsalves F, 1987. The Action of Divalent Zinc, Cadmium, Mercury, Copper and Lead on the Trans-Root Potential and Efflux of Excised Roots. Journal of Experimental Botany, 38 (5): 800-817.

Mazreku IN, Ahmetaj H, Aliko V, Bislimi K, Halili F, Halili J, 2017. Activity of Catalase (CAT), ALT and AST in Different Organs of Swiss Albino Mice Treated with Lead Acetate, Vitamin $\mathrm{C}$ and Magnesium-LThreonate. Journal of Clinical and Diagnostic Research, 11 (11): 1-4.

Norsharina I, Maznah I, Aied AA, Ghanya AN, 2011. Thymoquinone Rich Fraction from Nigella sativa and Thymoquinone are Cytotoxic Towards Colon and Leukemic Carcinoma Cell Lines. Journal of Medicinal Plant Research, 5 (15): 3359-3366.

Pari L, Murugan P, 2004. Protective Role of Tetrahydrocurcumin Against Erythromycin Estolate induced Hepatotoxicity. Pharmacological Research, 49: 481-486. 
Rastogi L, Feroz S, Pandey BN, Jagtap A, Mishra KP, 2010. Protection Against RadiationInduced Oxidative Damage by an Ethanolic Extract of Nigella sativa L. International Journal of Radiation Biology, 86 (9): 719-731.

Shrivastava R, Agrawal R, Parveen Z, 2011. A Review on Therapeutic Applications of Nigella sativa. Journal of Chemical Sciences, 1: 241-248.

Stefano G, Fiume L, Domenicali M, Busi C, Chieco P, Kratz F, 2006. Doxorubicin Coupled to Lactosaminated Albumin: Effects on Rats with Liver Fibrosis and Cirrhosis. Digestive and Liver Disease, 38 (6): 404-408.

Yesmin F, Rahman Z, Dewan JF, Helali AM, Rahman NIA, Alattraqchi AG, Ahmed Arefuddin, Yousuf R, Salam A, Haque M, 2013. Hepatoprotective Role of the Aqueous and N-Hexane Extracts of Nigella sativa Linn. in Experimental Liver Damage in Rats. Asian Journal of Pharmaceutical and Clinical Research, 6: 205-209.
Yoshioka T, Kawada K, Shimada T, Mori M, 1979. Lipid Peroxidation in Maternal and Cord Blood and Protective Mechanism Against Activated-Oxygen Toxicity in the Blood. American

Journal of Obstetrics and Gynecology, (3): 372-376.

Zhang J, Cao H, Zhang Y, Zhang Y, Ma J, Wang J, Gao Y,Zhang X, Zhang F, Chu L, 2013. Nephroprotective Effect of Calcium Channel Blockers Against Toxicity of Lead Exposure in Mice. Toxicology Letters, 218 (3): 273-280. 